\title{
Specific cutaneous involvement of a mixed-type mature plasmacytoid dendritic cell tumor in chronic myelomonocytic leukemia
}

\author{
Kronik myelomonositer lösemide mikst tip matür plasmositoid dendritik hücreli \\ tümörün spesifik kutanöz tutulumu
}

\section{Pelin Üstüner, ๑ Ali Balevi, ๑ Mustafa Özdemir, ๑ Cuyan Demirkesen*}

İstanbul Medipol University Faculty of Medicine, Department of Dermatology; *Department of Pathology, İstanbul, Turkey

\begin{abstract}
A 68-year-old man with chronic myelomonocytic leukemia (CMML), proven by bone marrow biopsy, presented to our clinic with pruritic indurated papules on his scalp, trunk and gluteal regions that have been present for two years. Purpuric, infiltrated miliary papules and petechiae were predominantly observed on his trunk, abdomen, back and legs. Histopathological examination revealed atypical monocytic cells with convoluted, irregularly shaped chromatin accompanied by histiocytes. He was finally diagnosed with CMML with specific cutaneous involvement of mixed-type mature plasmacytoid dendritic cell tumor. Immunohistochemical tests showed positive CD4, CD56, and CD123 mature plasmacytoid dendritic cells, positive CD1a indeterminate dendritic cells, and positive CD68 monocytic cells.

Mixed-type mature plasmacytoid dendritic cell tumor is known as a clinicopathological subtype of CMML that has the best prognosis, involving non-aggressive lesions. We conclude that identification of clinicopathologic subtypes in CMML will guide clinicians on chemotherapy protocols and estimation of survival.

Keywords: Chronic, dendritic cells, leukemia, myelomonocytic

Öz

Altmış sekiz yaşında kemik iliği biyopsisi ile tanısı doğrulanmış kronik myelomonositer lösemili (KMML) erkek hasta saçlı deride, gövde ve gluteal bölgelerde 2 yıldır var olan pruritik, endure papüller nedeniyle başvurdu. Ağılıklı olarak gövde, karın, bel ve bacak bölgelerinde yer alan purpurik, infiltre miliyer papüller ve peteşiler görüldü. Histopatolojik incelemede kıvrımlı, düzensiz şekilli kromatinli atipik monositik hücreler ve eşlik eden histiyositler görüldü. Hasta sonuç olarak KMML'nin matür plazmositoid dendritik hücreli tümör mikst tipinin spesifik deri tutulumu tanısı aldı. İmmünohistokimyasal testlerde CD4(+), CD56(+), CD123(+) matür plazmositoid dendritik hücreler, CD1a(+) belirsiz dendritik hücreler, CD68(+) monositik hücreler saptandı. Mikst tip matür plazmositoid dendritik hücreli tümör KMML'nin en iyi prognozlu ve agresif olmayan lezyonların görüldüğü klinikopatolojik alt tipi olarak bilinmektedir. KMML'nin klinikopatolojik alt tiplerinin belirlenmesinin klinisyenlere kemoterapi protokollarında ve sağkalım tahmininde rehber olduğu sonucuna vardık.
\end{abstract}

Anahtar Kelimeler: Kronik, dendritik hücreler, lösemi, myelomonositik

\section{Introduction}

Cutaneous involvement is seen in 6-10\% of lymphocytic and myeloid leukemias and $10-50 \%$ of monocytic leukemia cases $^{1}$. The differential diagnosis of a leukemic skin lesion located on the trunk includes a vast majority of cutaneous diseases, such as cutaneous malignancies, metastasis of visceral malignancies, Kaposi sarcoma, drug eruption, viral exanthem, syphilitic exanthem, pityriasis rosea, urticarial vasculitis, Sweet's syndrome, cutaneous pseudolymphoma, and cutaneous lymphomas². Chronic myelomonocytic leukemia (CMML) is characterized by an absolute monocytosis greater than $1 \times 10^{9} / \mathrm{L}$ in the peripheral blood that persists for at least three months. The diagnosis of CMML depends on

Address for Correspondence/Yazışma Adresi: Pelin Üstüner MD, İstanbul Medipol University Faculty of Medicine, Department of Dermatology, İstanbul,

Turkey Phone: +90 5052520223 E-mail: pelindogaustuner@gmail.com

Received/Geliş Tarihi: 29.08.2017 Accepted/Kabul Tarihi: 08.12.2017 ORCID ID: orcid.org/0000-0002-7885-0537

CCopyright 2018 by Turkish Society of Dermatology and Venereology

Turkderm-Turkish Archives of Dermatology and Venereology published by Galenos Yayınevi. 
greater than $1 \times 10^{9} / \mathrm{L}$ in the peripheral blood that persists for at least three months. The diagnosis of CMML depends on a combination of morphological, histopathological and chromosomal abnormalities in the bone marrow after exclusion of other conditions that can cause monocytosis ${ }^{3}$. Skin involvement of CMML is seen very rarely and mostly in patients over the age of $60^{4}$. The presence of specific skin lesions has been reported to result in a poor prognosis ${ }^{5}$.

In this report, we aimed to present a case of CMML and discuss his specific clinical lesions, immunohistochemical and prognostic variable features in the light of different clinicopathological subtypes of CMML.

\section{Case Report}

A 68-year-old man presented to our clinic with pruritic, indurated cutaneous lesions on the scalp, trunk and gluteal regions that have been present for the last two years (Figure 1a). Laboratory findings were typical of leukemia and bone marrow biopsy confirmed the diagnosis of CMML. Immunohistochemical studies of the bone marrow biopsy material provided negative results for the $B C R-A B L 1$ gene and the JAK2 V617F mutation. Blood analysis revealed the presence of leukoerythroblastosis, an absolute monocytosis $\left(2.3 \times 10^{9} / \mathrm{L}\right)$ and leukocytosis. Splenomegaly was also noted. The patient's medical history included hypertension, for which he was taking diuretics. He reported that he was working in the barrel chemicals industry and had been in contact with a suspicious hair dye a few months earlier. He was started on hydroxyurea after consultation with the hematology department. The leukocytosis was reduced with remarkable clinical improvement also in cutaneous lesions. After a few months, he presented to our clinic again with outspread lesions all over his trunk, arms, abdomen and legs. Dermatological examination revealed new widespread, purpuric, infiltrated miliary papules, petechiae and palpable purpuric lesions predominantly located on his trunk, abdomen, lumbar region and posterior compartment of the legs (Figure 1b-1d). The patient's condition did not improve after topical corticosteroid and anti-histaminic treatments. Considering a differential diagnosis of leukemic skin infiltration or leukocytoclastic vasculitis, punch biopsy material was taken from one of the papular lesions on the leg and trunk. Histopathological examination showed atypical monocytic cells with thin, convoluted, irregularly shaped chromatin and nucleus accompanied by reactive lymphocytes, eosinophils and histiocytes (Figure 2a). Vascular proliferation and extravasated erythrocytes were also noted.

In immunochemical analysis, we first examined CD4 as a T-cell marker and CD68 as a monocytic cell marker. The presence of plasmacytoid dendritic cell markers, such as CD123, TCL1 and CD303 and indeterminate dendritic cells markers such as CD56, CD1a, Langerin, and S100 were also analyzed. Positive CD4, CD56, CD303 and CD123 mature plasmacytoid dendritic cells (MPDC), CD1a indeterminate dendritic cells, and CD68 monocytic cells were seen (Figure 2b). S-100 was positive, but Langerin was negative. The coexistence of CD56, CD303, TCL1 and CD123 MPDCs with CD1a indeterminate dendritic cells was notable. The patient was finally diagnosed with CMML with specific cutaneous involvement of mixed-form MPDC tumor (MPDCT). Six months of hydroxyurea treatment resulted in remarkable improvement in skin lesions, and the pruritus almost completely

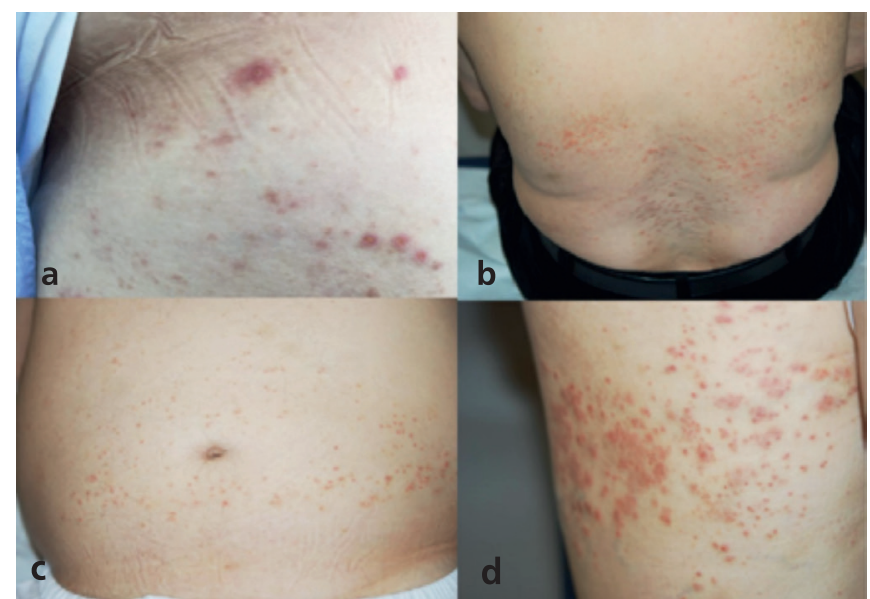

Figure 1. a) The pruritic and purpuric numerous papules on the gluteal regions. b) The widespread, purpuric, infiltrated miliary papules predominantly located on the patient's back and lumbar region. c) Palpable purpuric lesions predominantly located on the patient's abdomen. d) Petechiae on the posterior compartment of the patient's legs

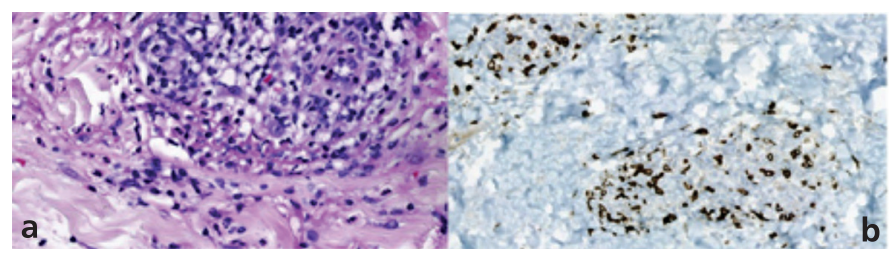

Figure 2. a) Atypical monocytic cells with thin, convoluted, irregularly shaped chromatin and nucleus accompanied by reactive lymphocytes, eosinophils and histiocytes (hematoxylin and eosin x200). b) Positive CD68 monocytic cells indicating the involvement of mixed-type mature plasmacytoid dendritic cell tumor in chronic myelomonocytic leukemia (CD68 x200)

resolved.

\section{Discussion}

Cutaneous involvement in leukemia is mostly seen in the acute myeloid and chronic lymphocytic forms. The prevalence is 2.1 to $30 \%$ and independent from factors, such as age and sex ${ }^{1}$. The diagnosis of leukemia cutis is often made either simultaneously with or after the diagnosis of systemic leukemia ${ }^{6}$. While $55-77 \%$ of patients with leukemia cutis have already been diagnosed with leukemia, 22-38\% of cases present with simultaneous onset of systemic symptoms and cutaneous findings ${ }^{2}$. In approximately $7 \%$ of cases, cutaneous lesions are seen many years before the manifestation of the disease ${ }^{2}$.

Leukemia cutis often presents with solitary or disseminated lesions on the head and neck or the trunk ${ }^{7}$. Generalized distribution can also be seen, especially in acute leukemia. In differential diagnosis, sarcoidosis, acute febrile neutrophilic dermatosis, cutaneous B-cell lymphoma, cutaneous positive CD30 (Ki-1) anaplastic large cell lymphoma, pseudolymphoma, and urticarial vasculitis should be considered and eliminated ${ }^{2,7,8}$. The specific cutaneous lesions of $C M M L$ are seen very rarely with a prevalence of $10 \%$. In some cases, CMML can be transformed to acute myeloid leukemia that is also accompanied by the lesions of myeloid leukemia cutis ${ }^{9}$. 
Table 1. Differential diagnosis between different histopathological subtypes of chronic myelomonocytic leukemia ${ }^{1,8,10,11-13}$

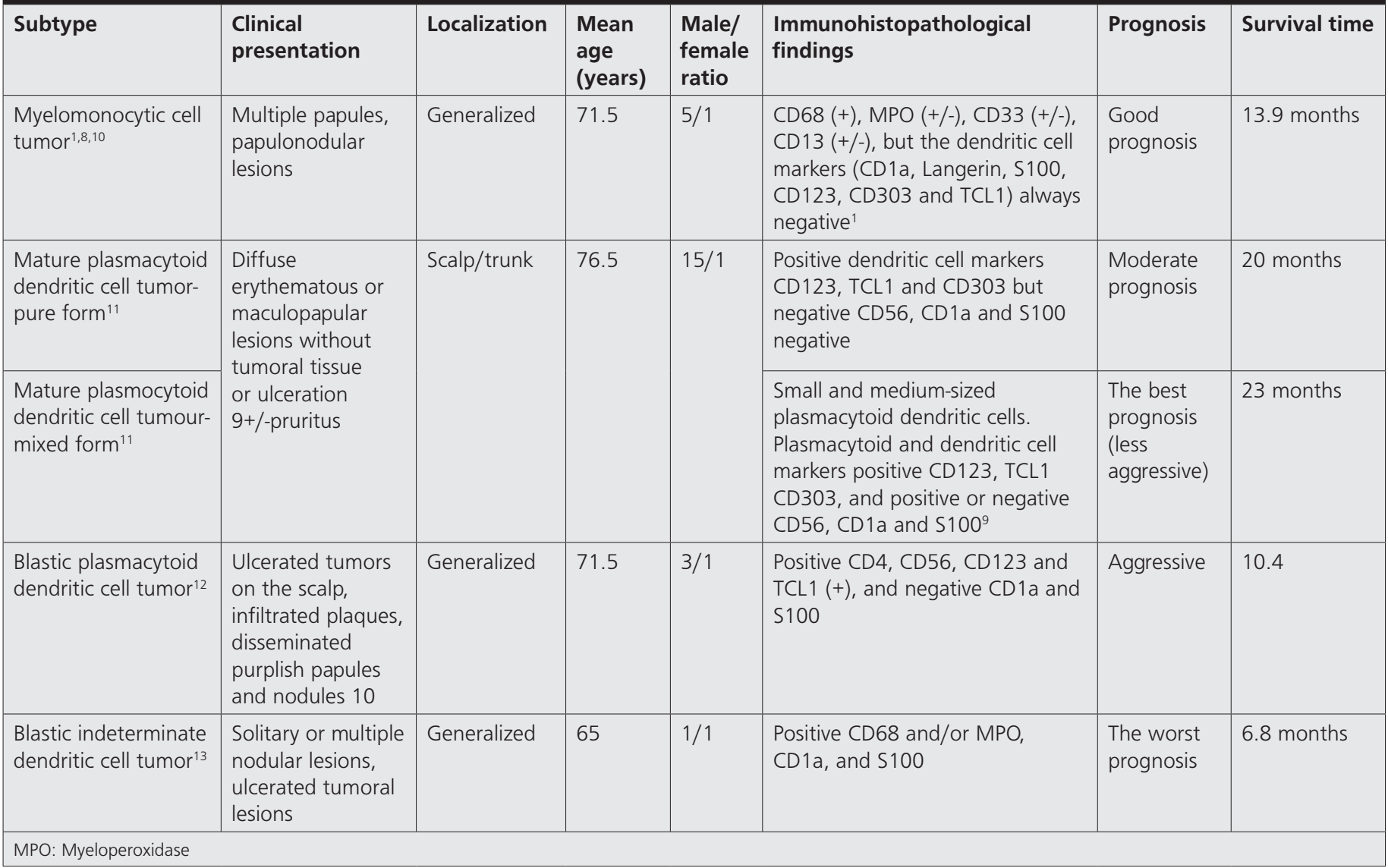

Vitte et al. ${ }^{10}$ reported four different clinicopathological subtypes of cutaneous involvement in CMML with different prognostic courses; myelomonocytic cell tumor, MPDCT, blastic PDCT (BPDCT) and blastic indeterminate dendritic cell tumor (BIDCT). Table 1 presents detailed information for the differential diagnosis of each subtype.

BPDCT is rarely diagnosed in children with only 36 cases have been reported up to date. In the literature, a 6-year-old boy with subcutaneous hemorrhage and a cyanotic brownish tumor on the medial surface of his right thigh was reported to have BPDCT with involvement of both skin and myeloid cells ${ }^{11}$. Bone marrow cytology assessment has revealed that the dendritic cell-like population constituted $30 \%$ of the total cell count and immunophenotyping has shown the plasmocytoid dendritic cell population ${ }^{11}$. Among all subtypes, BIDCT has the worst prognosis. To date, only one patient with BIDCT accompanied by Langerhans cell histiocytosis has been reported in the literature ${ }^{12}$.

In the literature, a 67-year-old man with a three-year history of stable CMML has also been reported to develop splenomegaly and acute onset of skin lesions ${ }^{13}$. Histopathological examination revealed a dense infiltrate of histiocytic cells morphologically resembling Langerhanstype cells (lacking histopathological features of frank atypia) and the immunophenotype of an indeterminate cell histiocytosis (positive S100, CD1a and Langerin) ${ }^{13}$. Furthermore, two additional cases of a rare distinct neoplasm, cutaneous indeterminate dendritic cell neoplasm (IDCN), have been described in the literature ${ }^{14}$. IDCN was shown to present as a mostly cutaneous proliferation of histiocytoid cells, predominantly in adults. As characteristic for IDCN, the patients were found to be positive for CD1a, negative for Langerin, and variably positive for S100, and the condition was strongly associated with the presence of a second hematopoietic malignancy ${ }^{14}$.

In the current case, the patient was diagnosed with the mixed form of subtype MPDCT based on the positive CD123, TCL1, CD303 and CD56, CD1a, and S100 findings according to the presence of plasmacytoid and indeterminate dendritic cells. We also observed the presence of diffuse erythematous maculopapular lesions and pruritus, which are all typical for this subtype. The absence of a tumoral lesion or ulceration was also noted. With a non-aggressive course and good prognosis, the patient's condition considerably improved.

In this paper, we presented a case of CMML involving the mixed form of MPDCT with a good prognosis, and discussed the specific clinical lesions, immunohistochemical and prognostic variable features in the light of the four clinicopathological subtypes of CMML. It is a hematopoietic stem cell neoplasm exhibiting both myelodysplastic and myeloproliferative features. Specific cutaneous involvement of lesions indicates the increase in disease activity, progression or blast transformation ${ }^{5,10}$. Cutaneous lesions of CMML exhibit heterogeneous histopathological features that can be challenging in the recognition of CMML. All the findings show variable features of a spectrum in CMML including the proliferation of myelomonocytic and dendritic cells. The identification of different subtypes of CMML is important for clinicians in assessing prognosis and estimating survival. 


\section{Ethics}

Informed Consent: Informed consent form was obtained from the patient.

Peer-review: External and internal peer-reviewed.

\section{Authorship Contributions}

Surgical and Medical Practices: P.Ü., Concept: P.Ü., Design: P.Ü., A.B., Data Collection or Processing: P.̈̈., C.Ö., Analysis or Interpretation: P.Ü., A.B., M.Ö., C.D., Literature Search: P.̈̈., Writing: P.̈̈.

Conflict of Interest: No conflict of interest was declared by the authors.

Financial Disclosure: The authors declared that this study has received no financial support.

\section{References}

1. Kaddu S, Zenahlik P, Beham-Schmid C, Kerl H, Cerroni L: Specific cutaneous infiltrates in patients with myelogenous leukemia: a clinicopathologic study of 26 patients with assessment of diagnostic criteria. J Am Acad Dermatol 1999:40:966-78.

2. Martínez-Leboráns L, Victoria-Martínez AM, Torregrosa-Calatayud JL, Alegre de Miquel V: Leukemia cutis: A report of 17 cases and a review of the literature. Actas Dermosifiliogr 2016;107:65-9.

3. Pala Ç, Eser B: Kronik myelomonositik lösemi: Turkiye Klinikleri J HematolSpecial Topics 2013;6:53-9.

4. Orazi A, Bennett JM, Germing U: Chronic myelomonocytic leukaemia WHO classification of tumors of haematopoietic and lymphoid tissues. Ed: Swerdlow SH, Campo E, Harris NL. Lyon, France, IARC press, 2008:76-9.
5. Mathew RA, Bennett JM, Liu JJ, et al: Cutaneous manifestations in CMML: Indication of disease acceleration or transformation to $\mathrm{AML}$ and review of the literature. Leuk Res 2012;36:72-80.

6. Çetin G, Ar MC, Börkü B, Cerit A, Gözübenli K: Akut myeloid lösemide nadir görülen bir cilt bulgusu: Cilt tutulumu. İstanbul Med J 2013;14:124-5.

7. Grunwald MR, McDonnell MH, Induru R, Gerber JM: Cutaneous manifestations in leukemia patients. Semin Oncol 2016;43:359-65.

8. Wagner G, Fenchel K, Back W, Schulz A, Sachse MM: Leukemia cutis epidemiology, clinical presentation, and differential diagnoses. J Dtsch Dermatol Ges 2012;10:27-36.

9. Pont $V$, Miquel FJ, Grau TC, Hernández F, Sánchez-Carazo JL, Aliaga A: Skin involvement in chronic myelomonocytic leukaemia as a predictor of transformation into acute myeloid leukaemia. J Eur Acad Dermatol Venereol 2001;15:260-2.

10. Vitte $F$, Fabiani B, Bénet $C$, et al: Specific skin lesions in chronic myelomonocytic leukemia: a spectrum of myelomonocytic and dendritic cell proliferations: a study of 42 cases. Am J Surg Pathol 2012;36:1302-16.

11. Mizia-Malarz A, Sobol-Milejska G: Blastic plasmocytoid dendritic cell neoplasm with skin and myeloid location. J Pediatr Hematol Oncol 2018:40:29-31.

12. Hammami H, Zaraa I, El Euch $D$, et al: Letterer-Siwe disease associated with chronic myelomyonocytic leukemia: a fortuitous association? Acta Dermatovenerol Alp Pannonica Adriat 2010;19:45-8.

13. Loghavi S, Curry JL, Garcia-Manero G, et al: Chronic myelomonocytic leukemia masquerading as cutaneous indeterminate dendritic cell tumor: Expanding the spectrum of skin lesions in chronic myelomonocytic leukemia. J Cutan Pathol 2017;44:1075-9.

14. Horna P, Shao H, Idrees A, Glass LF, Torres-Cabala CA: Indeterminate dendritic cell neoplasm of the skin: A 2-case report and review of the literature. $J$ Cutan Pathol 2017;44:958-63. 